\title{
ACUTE UTERINE INVERSION- A CASE REPORT
}

\author{
Nirmala Sharma ${ }^{1}$, Neha Seehra², Amar Singh ${ }^{3}$
}

${ }_{1}^{1}$ Senior Professor and Head of Unit, Department of Obstetrics and Gynaecology, Jay Kay Hospital, Jaipur, Rajasthan, India. ${ }^{2}$ Assistant Professor, Department of Obstetrics and Gynaecology, J. K. Lon Hospital, Jaipur, Rajasthan, India.

${ }^{3}$ Resident, Department of Obstetrics and Gynaecology, J. K. Lon Hospital, Jaipur, Rajasthan, India.

HOW TO CITE THIS ARTICLE: Sharma N, Seehra N, Singh A. Acute uterine inversion- a case report. J. Evolution Med. Dent. Sci. 2018;7(50):5398-5399, DOI: 10.14260/jemds/2018/1194

\section{PRESENTATION OF CASE}

Puerperal inversion of uterus is a rare but well-known lifethreatening complication occurring during the $3^{\text {rd }}$ stage of labour. The incidence of uterine inversion is approximately 1 in 2500 to 1 in 3700 deliveries. ${ }^{1,2}$ When not immediately identified, the massive $\&$ often underestimated blood loss can lead to hypovolemic shock \& maternal death that can reach upto $15 \%$ in some series. ${ }^{3}$ Mismanaged third stage of labour being the most common cause followed by cord traction on an abnormally adherent placenta, precipitate labour, \& short umbilical cord in its aetiology. ${ }^{4}$ The diagnosis of puerperal uterine inversion is mainly clinical, based on 3 elements: haemorrhage, shock \& strong pelvic pain. ${ }^{5}$ Shock results from hypovolemia which is secondary to bleeding and to vagal reaction associated to the stretching of nerve fibres in uterine ligaments. ${ }^{6}$

A 26 years old primipara was referred to Jay Kay Lon Hospital, Govt. Medical College, Kota, Rajasthan, with neurogenic shock. She had a vaginal delivery, 6 hours ago in the community health centre, Deoli (Dist. Tonk), Rajasthan and had given birth to a healthy baby. The patient was herself a staff nurse and had a history of precipitate labour. Uterus inverted soon after the delivery but was referred as a case of uterine fibroid or uterine inertia. On arrival to our hospital, patient's general condition was poor, peripheral pulses not palpable, B.P. was not recordable. On per abdomen examination: dimpling of uterus noted, per speculum examination- 2 packs removed from the vagina, a fleshy mass seen in the vagina, same was bleeding and cervical ring felt around the prolapsed mass.

\section{CLINICAL DIAGNOSIS}

Primipara with Acute Uterine Inversion with Neurogenic Shock.

\section{DIFFERENTIAL DIAGNOSIS}

- Uterine Inversion

- Fibroid Polyp

- Placental Polyp

- Prolapsed Uterus

- Cervical Hypertrophy

- Uterine Inertia.

'Financial or Other Competing Interest': None.

Submission 31-10-2018, Peer Review 25-11-2018,

Acceptance 02-12-2018, Published 10-12-2018.

Corresponding Author:

Neha Seehra,

\#110-A, Shreenath Puram,

Kota, Rajasthan, India.

E-mail: dr.nehaseehra@gmail.com

DOI: $10.14260 /$ jemds/2018/1194

\section{(c) $(1) \subseteq$}

\section{DISCUSSION OF MANAGEMENT}

Immediate resuscitation must be started in these cases, simultaneously with the efforts to reduce inversion. Conservative management such as manual replacement (Johnson's Manoeuvre) and the hydrostatic method (O'Sullivan's Technique) should be tried first.

If these measures fail to achieve success, surgical intervention is required. Among the surgical procedures, Huntington's procedure and Haultain procedure are the most popular. Of the vaginal procedures, Spinelli method or Kustner method may be approached.

In our case, we started immediate resuscitation. Wide bore cannula secured, intravenous fluid given, samples sent for cross matched blood and investigations. Patient was shifted to emergency O.T. Prophylactic broad spectrum antibiotics administered intravenously. Manual replacement tried but failed. Open reduction by laparotomy decided under general anaesthesia. Abdomen was opened, cup of inversion noted with indrawn fallopian tubes \& ovary. Huntington's method was done by applying a Babcock's clamp in the crater $2 \mathrm{~cm}$ below the ring and gentle upward traction given, new clamps were applied $2 \mathrm{~cm}$ below the previous one, repeating until complete replacement done, meanwhile assistant applied upward pressure through vagina to facilitate the procedure. Once repositioning was done, uterotonics started till uterus contracted. Abdomen closed back, patient stood the procedure well. Patient was observed in the intensive care unit post operatively. 2 units of pack cell volume transfused intra-operatively and 1 unit of packed cell volume post operatively. IV fluids and IV antibiotics given, breast feeding was initiated the next day. Patient was discharged after 5 days. This case is unusual because it was misdiagnosed as fibroid uterus at periphery, whereas its correct diagnosis and prompt treatment by surgical means was done at tertiary care hospital without putting an incision over uterus.

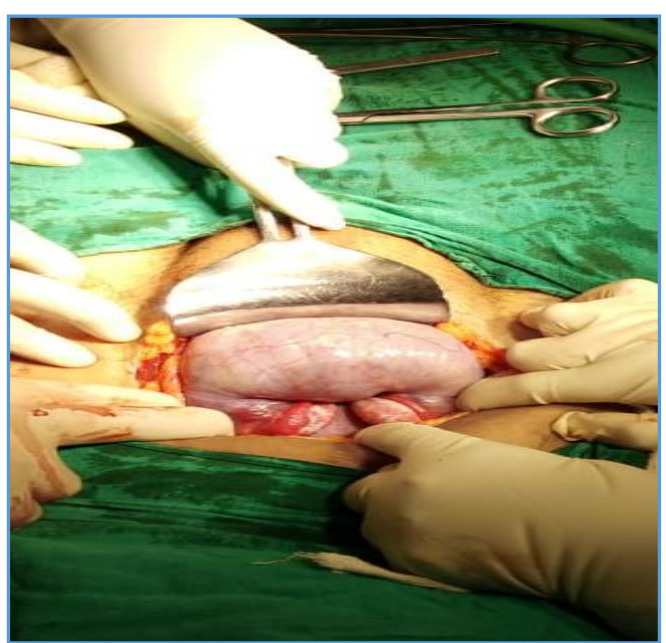

Figure 1. Cup of Uterine Inversion seen at Laparotomy 


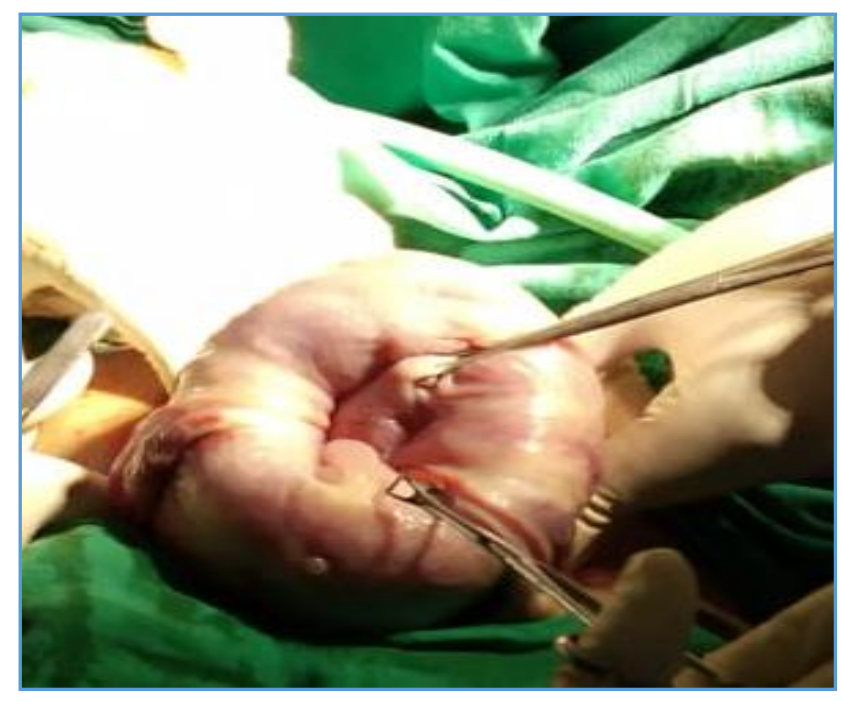

Figure 2. Repositioning by Huntington's Procedure

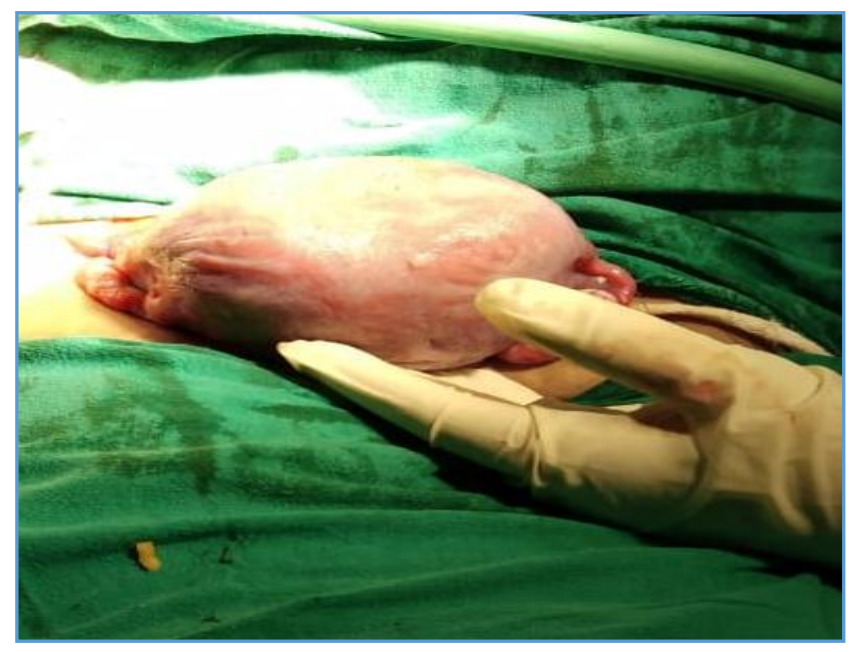

Figure 3. After Correction of Inversion
FINAL DIAGNOSIS

Acute Uterine Inversion in Neurogenic Shock.

\section{REFERENCES}

[1] You WB, Zahn CM. Postpartum hemorrhage: abnormally adherent placenta, uterine inversion and puerperal hematomas. Clin Obstet Gynecol 2006;49(1):184-97.

[2] Robson S, Adair S, Bland P. A new surgical technique for dealing with uterine inversion. Aust N Z J Obstet Gynecol 2005;45(3):250-1.

[3] Hostetler D, Bosworth MF. Uterine inversion: a lifethreatening obstetric emergency. J Am Board Fam Pract 2000;13(2):120-3.

[4] Mishra R, Yerra A. Maternal injuries during labour. Chapter - 31. Ian Donald's Practical obstetric problems. $7^{\text {th }}$ edn. Lippincott 2014: p. 596-7.

[5] Wendel PJ, Cox SM. Emergent obstetric management of uterine inversion. Obstet Gynecol Clin North Am 1995;22(2):261-74.

[6] Miras T, Collet F, Seffert P. acute puerperal uterine inversion: two cases. J Gynecol Obstet Biol Repord (Paris) 2002;31(7):668-71. 